\title{
A longitudinal study on peri-implant bone changes in elderly patients with systemic complications
}

\author{
Estudo longitudinal das variações ósseas peri-implantes em pacientes \\ idosos e com complicações sistêmicas
}

\author{
Rejane Eliete Luz Pedro* \\ Micheline Sandini Trentin ${ }^{* *}$ \\ João Paulo De Carli** \\ Daiana Jacobi Lazarotto*** \\ Ângelo José Gonçalves Bós ${ }^{* * * *}$ \\ Luiz Renato Paranhos ${ }^{* * * * *}$ \\ Bethânia Molin Giaretta De Carli $i^{* * * * *+}$ \\ Maria Salete Sandini Linden
}

\section{Abstract}

Objective: The present study radiographically assessed the maintenance of osseointegration in adult patients with mean age of 55.3 years, with dental implants and respective prosthetic implants. Subjects and method: Therefore, periapical radiographs were taken of 36 implants installed in 11 patients for the calculation of the marginal bone level (mesial and distal), using the software Image ${ }^{T M}$ Toll (in pixels). Negative difference greater than 0.01 pixels between the initial measurement and after 1 year was considered bone loss. The average age of patients in the study was compared to mesial and distal peri-implant bone loss, using the " $t$ " test. The association between bone loss, gender, presence of osteoporosis, thyroid disease, smoking, alcoholism, and bruxism were tested by chi-square test or Fisher's exact test. Results: Measurements of distal osseointegration observed on radiographs showed peri-implant bone loss in 19 implants (53\%), while the mesial peri-implant bone loss was found in 17 implants (47\%). Patients with distal bone loss had lower average age (52.1 \pm 6.27 years) than those without distal loss (58.5 \pm 10.26 years) $(p=0.0576)$. Conclusion: It was observed that increasing age is inversely related to peri-implant bone loss. Patients with good systemic health, even with advanced age, are candidates for implants.

Keywords: Dental implants. Alveolar bone loss. Longitudinal studies.

\section{Introduction}

The goal of restorative treatment with dental implants is to preserve the integrity of the intraoral structures while recovering the aesthetics and the functionality of the stomatognathic system $^{1,2}$. Nowadays, the elderly who suffer from edentulism are increasingly asking their clinicians for implant-supported prosthetic rehabilitations ${ }^{3}$.

Implant-supported restorations have been proved to be successful by literature ${ }^{4-7}$. According to Baumgarten ${ }^{8}$, long-term stability of the peri-implant bone crest is critical for that success, both from the functional and the aesthetical point of view. Misch ${ }^{9}$ states that early loss of peri-implant bone crest is a phenomenon of paramount clinical significance for which numerous explanations have been proposed. Finding out why the peri-implant bone crest may be lost is important to prevent and avoid it, thus improving the overall success of the implant-prosthesis construct ${ }^{10-12}$.

DDS, PhD, Posgraduate student, Pontifical Catholic University (PUCRS), Porto Alegre, RS, Brazil.

DDS, PhD, Professor, University of Passo Fundo (UPF), RS, Brazil.

DDS, University of Passo Fundo (UPF), RS, Brazil.

**** DDS, PhD, Professor, Pontifical Catholic University (PUCRS), Porto Alegre, RS, Brazil.

$* * * * *$ DDS, PhD, Professor, Federal University of Sergipe, Lagarto, SE, Brazil.

DDS, MS, Professor University of Passo Fundo (UPF), RS, Brazil. 
Systemic conditions, along with nutritional and parafunctional habits may all be harmful to dental implants. Diseases that affect healing may worsen surgical outcomes, and metabolic alterations and bone loss may affect the long-term success of the implant. However, the existence of a disease does not necessarily prevent implant therapy. In fact, it is known that, when controlled, a systemic condition does not change implant survival rates significantly ${ }^{13-16}$.

The aim of this longitudinal study was to observe the radiographic changes at the mesial and distal sides of the peri-implant bone as well as their determinants in patients rehabilitated with implant-supported prostheses.

\section{Subjects and method}

This study was approved by the Ethics Committee in Research of the University of Passo Fundo, state of Rio Grande do Sul, Brazil (CAAE 00.49.0.398.000-09).

We conducted a longitudinal observational study with 11 adult Caucasian patients (mean age of 55.3 years) randomly selected from our patient base at the Dental School of University of Passo Fundo. Patients were treated between September and December 2009, and received a total of 36 dental implants (Conexão Sistema de Próteses, Arujá, state of São Paulo, Brazil) that were subsequently restored.

At the time of definitive prosthesis delivery, participants filled a health questionnaire (history of osteoporosis, thyroid disease, smoking, alcohol, and bruxism) and had periapical radiographs taken with individualized positioning jigs (Indusbelo ${ }^{\mathrm{TM}}$, Londrina, Paraná, Brazil). Radiographs were repeated one year after prosthetic delivery. At both ti- mes, radiographic films were automatically processed (A / T $2000 \mathrm{X}^{\mathrm{TM}}$, Air Techniques, Hicksville, NY, USA), and then scanned (UMAX Astra 2400SLT, Taiwan, China). The implant platform was determined as the reference point from which mesial and distal marginal bone levels were measured. Calculations were performed with the UTHSCSA Image Tool $^{\mathrm{TM}}$ software (http://compdent.uthscsa.edu/dig/ itdesc.html). These bone levels were measured and expressed in millimeters. True bone resorption was calculated comparing the marginal bone to implant level on the postoperative radiograph, with the follow-up radiographs. Both mesial and distal measurements were taken for each individual implant.

Mean patient age was compared between implants with and without mesial and distal bone loss, using the "t" test. The association between mean bone loss, gender, presence of osteoporosis, thyroid disease, smoking, alcoholism, and bruxism were tested by chi-square test or Fisher's exact test. Statistical analysis was performed using the Epi $\mathrm{Info}^{\mathrm{TM}}$ 3.5.1. An alpha error inferior to 0.05 was considered significant and error between 0.1 and 0.05 was considered indicative of significance.

\section{Results}

The implants were classified into two groups: those with high bone loss, when the difference between final and initial measurements reached a $\mathrm{p}>$ 0.01 index $^{17}$, and those with low bone loss.

Thirteen questionnaires were positive for some sort of systemic disease, with some patients reporting more than one condition (9 with thyroid disease, 2 with bruxism, and 2 with osteoporosis). Two individuals reported social drinking and one reported smoking (Table 1).

Table 1 - Relationship between bone loss, implant dimensions, age, and gender of the patient

\begin{tabular}{c|c|c|c|c}
\hline Distal bone loss & $\begin{array}{c}\text { Implant diameter } \\
(\mathrm{mm})\end{array}$ & $\begin{array}{c}\text { Implant length } \\
(\mathrm{mm})\end{array}$ & $\begin{array}{c}\text { Age } \\
\text { (years })\end{array}$ & $\begin{array}{c}\text { Gender } \\
(\mathrm{F} / \mathrm{M})\end{array}$ \\
\hline Yes & $3.95 \pm 0.4512$ & $10.53 \pm 1.7895$ & 52.06 .27 & $15 / 4$ \\
No & $3.97 \pm 0.3308$ & $10.86 \pm 1.5119$ & 58.510 .26 & $11 / 6$ \\
p value & $0.8302^{*}$ & $0.5909^{*}$ & $0.0576^{*}$ & $0.2811^{* *}$ \\
\hline
\end{tabular}

* Student $t$ test, Fisher's exact test ${ }^{* *}$

Considering the 36 implants studied, we found bifocal bone loss (both mesial and distal) in 12 $(33.3 \%)$ implants, and unifocal bone loss (mesial or distal) in other 12 implants $(33.3 \%)$. Twelve implants $(33.3 \%)$ did not show any measurable signs of peri-implant bone resorption. Regardless of being uni- or bifocal, distal bone loss was observed in 19 implants (53\%), while mesial bone loss was identified in 17 implants (47\%).
When crossing mean patient age with bone loss, it seemed that lower age could be considered a significant factor for increased bone loss (Table 2). The proportion of women with bone loss was greater than men, but not significantly. 


\begin{tabular}{|c|c|c|c|c|c|c|c|c|c|c|}
\hline \multirow[b]{2}{*}{ Bone loss distal } & \multicolumn{2}{|c|}{ Bruxism } & \multicolumn{2}{|c|}{ Smoking } & \multicolumn{2}{|c|}{ Osteoporosis } & \multicolumn{2}{|c|}{ Thyroid disease } & \multicolumn{2}{|c|}{ Alcoholism } \\
\hline & Yes & No & Yes & No & Yes & No & Yes & No & Yes & No \\
\hline Yes & 1 & 18 & 2 & 17 & 0 & 19 & 5 & 14 & 2 & 17 \\
\hline No & 1 & 16 & 4 & 13 & 2 & 15 & 4 & 13 & 6 & 11 \\
\hline $\mathrm{p}^{*}$ value & \multicolumn{2}{|c|}{0.7286} & \multicolumn{2}{|c|}{0.2757} & \multicolumn{2}{|c|}{0.2159} & \multicolumn{2}{|c|}{0.5773} & \multicolumn{2}{|c|}{0.0829} \\
\hline
\end{tabular}

In the relationship between bone loss and clinical characteristics of the participants there was no significant association between the variables.

\section{Discussion}

In this study, logistic regression showed that age could be a protective factor for peri-implant bone loss, since implants in older patients showed a statistically lower chance of having distal bone loss (Table 2). The relation between age and bone loss may have been influenced by the fact that women included in this study could be in menopause, when accelerated bone loss is more pronounced than in men. Such finding was observed in other studies, which suggested that early menopause could be a risk factor for bone loss ${ }^{18,19}$.

A survey ${ }^{20}$ assessing the risk factors associated with implant failure found that older patients were at higher risk, as well as smokers, diabetic patients, head and neck cancer patients treated with radiotherapy, and those in use of estrogen after menopause. However, the present study found that implant failure was not significantly increased in older patients. It seems that diseases such as osteoporosis, diabetes, blood dyscrasias and advanced age are not absolute contraindications for implant-supported dental restorations.

In 2002 a study ${ }^{20}$ investigated implant success in controlled hypothyroidism patients. Twenty-seven female patients with a confirmed medical history of hypothyroidism were selected and compared to 29 control patients matched for age, gender, location of the implants (maxilla or mandible), type of restoration, and condition of the opposing dental arch. Other factors were studied such as medical history, medications, smoking, bone quality and quantity, but implant failure rates were not statistically different between groups $(p=0.781)$. This study suggested that patients with controlled hypothyroidism were not at higher risk of implant failure, and that thyroid disease was not a contraindication for treatment with dental implants. Likewise, our thyroid patients did not seem to be at higher risk for peri-implant bone loss.
A microbiological and radiographic ${ }^{17}$ evaluation was performed in 10 patients (mean age 55 years) with 12 Nobel Direct ${ }^{\mathrm{TM}}$ implants at intervals of 6 months, and 2 years after prosthesis installation. Among the 12 implants placed, 3 had failed after 6 months (bone loss $>3 \mathrm{~mm}$ ), and were histologically assessed after explanted. The average peri-implant bone loss was $2 \mathrm{~mm}( \pm 1.1 \mathrm{~mm})$ after 2 years. Comparing the earlier study to the present investigation, we seemed to have obtained greater success since none of the 36 implants placed was lost. Using a similar sample in age, we obtained an average bone gain of $1.13 \mathrm{~mm}$ with a greater dispersion (SD - 6.94).

Risk factors for implant failure may be divided into two main categories, as previously reported ${ }^{15}$ : firstly, the factors related to the surgical technique, the type and location of the implant, the time gap between tooth extraction and implant placement, and the delay in prosthetic loading; secondly, the factors related to the patient's clinical condition such as uncontrolled diabetes, alcohol abuse, and smoking. Smoking was the focus of the study mentioned above ${ }^{15}$ in which a sample of 650 patients with a total of 1628 implants inserted showed that initial rates of implant loss for non-smokers and smokers were $3.32 \%$ and $2.81 \%$, respectively. Univariate and bivariate analyzes failed to show any statistical association between early implant losses and frequency of tobacco, suggesting that cigarette smoking may not be considered a risk factor for implant failure. These findings are consistent with the results of this study that showed no influence of smoking on peri-implant bone loss.

To explore the possible relationship between peri-implant bone loss and generalized habits of smoking and alcohol consumption, a 3-year prospective clinical study ${ }^{21}$ followed 185 patients who had received 514 implants. The results showed that marginal bone loss was significantly related to increased consumption of alcohol and tobacco, and increased levels of plaque and gingival inflammation. Our results were different as we failed to show any association between smoking and significant peri-implant bone loss. However, we have to consider that our sample is much smaller and our follow-up is shorter. 


\section{Conclusion}

In summary, our findings suggest that increasing age is not directly related to peri-implant bone loss, and therefore healthy elderly patients might be good candidates for implant-supported oral rehabilitations. Nevertheless, more longitudinal studies are needed to investigate the interplay of systemic conditions, age, gender, and implant treatment.

\section{Resumo}

Objetivo: O presente estudo avaliou radiograficamente a manutenção da osseointegração em pacientes adultos com média de idade de 55,3 anos, com implantes dentários e respectivas reabilitações protéticas. Sujeitos e método: Tomadas radiográficas periapicais foram realizadas em 36 implantes instalados em 11 pacientes, para a medida do nível ósseo marginal (mesial e distal), utilizando-se o software Image Toll ${ }^{\circledR}$ (em pixels). Diferença negativa maior do que 0,01 pixels entre a medida inicial e após um ano foi considerada perda óssea. As médias de idade dos pacientes do estudo foram comparadas com perda óssea peri-implantar mesial e distal por meio do teste " $t$ ". A associação entre perda óssea, sexo, presença de osteoporose, doença da tireoide, tabagismo, alcoolismo e bruxismo foram avaliados pelo teste qui-quadrado ou teste exato de Fisher. Resultados: Medidas da osseointegração distal observadas nas radiografias mostraram perda óssea peri-implantar em 19 implantes (53\%), enquanto perdas ósseas peri-implantares mesiais ocorreram em 17 implantes (47\%). Pacientes com perda óssea distal apresentaram menor média de idade $(52,1 \pm 6,27$ anos) do que aqueles sem perda distal $(58,5 \pm 10.26$ anos) $(p=0,0576)$. Conclusão: Observou-se que o aumento da idade foi inversamente relacionado à perda óssea peri-implantar. Pacientes com boa saúde sistêmica, embora com idade avançada, são candidatos à instalação de implantes.

Palavras-chave: Implantes dentários. Perda óssea alveolar. Estudos longitudinais.

\section{References}

1. Neves FD, Fones D, Bernardes SR, do Prado CJ, Neto AJ. Short implants - an analysis of longitudinal studies. Int J Oral Maxillofac Implants 2006; 21(1):86-93.

2. Chandki R, Kala M. Natural tooth versus implant: a key to treatment planning. Oral Implantol 2012; 38(1):95-100.

3. Narby B, Kronström M, Söderfeldt B, Palmqvist S. Changes in attitudes toward desire for implant treatment: a longitudinal study of a middle-aged and older Swedish population. Int J Prosthodont 2008; 21(6):481-5.

4. Romeo E, Lops D, Margutti E, Ghisolfi M, Chiapasco M, Vogel G. Long-term survival and success of oral implants in the treatment of full and partial arches: a 7-year prospective study with the ITI dental implant system. Int J Oral Maxillofac Implants 2004; 19(2):247-59.

5. Waasdorp JA, Evian CI, Mandracchia M. Immediate placement of implants into infected sites: a systematic review of the literature. J Periodontol 2010; 81(6):801-8.

6. Van Steenberghe D, Lekholm U, Bolender C, Folmer T, Henry P, Herrmann I, et al. Applicability of osseointegrated oral implants in the rehabilitation of partial edentulism: a prospective multicenter study on 558 fixtures. Int $\mathrm{J}$ Oral Maxillofac Implants 1990; 5(3):272-81.
7. Lekholm U, Gunne J, Henry P, Higuchi K, Linden U, Bergstrom C, et al. Survival os the Brånemark implant in partially edentulous jaws: a 10-year prospective multicenter study. Int J Oral Maxillofac Implants 1999; 14(5):639-45.

8. Baumgarten H. A new implant design for crestal bone preservation: initial observations and case report. Pract Proced Aesthet Dent 2005; 17(10):735-40.

9. Misch CE. Prótese sobre implantes. 2. ed. São Paulo: Editora Santos; 2006.

10. Machtei E, Mahler D, Oettinger-Barak E. Dental implants placed in previously failed sites: survival rate and factors affecting the outcome. Clin Oral Implants Res 2008; 19(3):259-64.

11. Malchiodi L, Cucchi A, Ghensi P, Consonni D, Nocini PF. Influence of crown-implant ratio on implant success rates and crestal bone levels: a 36-month follow-up prospective study. Clin Oral Implants Res 2013; 15(1):130-42.

12. Bilge G-R, Mehmet Y, Senem O, Ebru DT, Gulumser E. Survival and success of ITI implants and prostheses: retrospective study of cases with 5-year follow-up. Eur J Dent 2009; 3(1):42-9.

13. Hwang D, Wang HL. Medical contraindications to implant therapy: part II: relative contraindications. Implant Dent 2007; 16(1):13-23.

14. Klemetti E, Kolmakov S, Kroger H. Pantomography in assessment of the osteoporosis risk group. Scand J Dent Res 1994; 102(1):68-72.

15. Sverzut AT, Stabile G, Moraes M. The influence of tobacco on early dental implant failure. J Oral Maxillofac Surg 2008; 66(5):1004-9.

16. Attard NJ, Zarb GA. A study of dental implants in medically treated hypothyroid patients. Clin Implant Dent Relat Res $2002 ; 4(4): 220-31$

17. Van de Velde T, Thevissen E, Persson R, Johansson C, De Bruyn H. Two-year outcome with Nobel Direct implants: a retrospective radiographic and microbiologic study in 10 patients. Clin Implant Dent Relat Res 2009; 11(3):183-93.

18. Svejme O, Ahlborg HG, Nilsson JA, Karlsson MK. Low $\mathrm{BMD}$ is an independent predictor of fracture and early menopause of mortality in post-menopausal women - A 34year prospective study. Maturitas 2013; 74(4):341-45.

19. Buyukkaplan US, Guldag MU, Yildiz M, Gumus BA. Comparison of mandibular bone mineral density in osteoporotic, osteopenic and normal elderly edentulous subjects measured by the dual-energy X-ray absorptiometry technique. Gerodontology 2012; 29(2):e1098-1102.

20. Moy PK, Medina D, Shetty V, Aghaloo TL. Dental implant failure rates and associated risk factors. Int J Oral Maxillofac Implants 2005; 20(4):569-77.

21. Galindo-Moreno P, Fauri M, Avila-Ortiz G, Fernández-Barbero JE, Cabrera-León A, Sánchez-Fernández E. Influence of alcohol and tobacco habits on peri-implant marginal bone loss: a prospective study. Clin Oral Implants Res 2005; 16(5):579-86.

\section{Corresponding author:}

Rejane Eliete Luz Pedro

Rua Lava Pés, 875, Centro

Passo Fundo, Rio Grande do Sul, Brazil

ZIP Code 99010-170

Phone: +5554 33117158 /

+555499843949

E-mail: relpodonto@gmail.com

Recebido: 29/07/2013. Aceito: 08/10/2013. 